\title{
Behavior of Hollow Core Slabs Reinforced with GFRP Prestressing Bars
}

\author{
A. M. Elhashimy, W. F. Tawhed, Mohamed H. Agamy
}

\begin{abstract}
An experimental program was designed to study the behavior of full-scale hollow core slabs prestressed with Glass Fiber-Reinforced Polymer (GFRP) bars in the concrete laboratory at the college of engineering, Mataria, Helwan University, Cairo, Egypt. The hollow core slabs were load-tested under uniformly distributed load. The GFRP bars were manufactured from locally available materials with a $10 \mathrm{~mm}$ nominal diameter. To improve the bond properties between the bars and concrete, GFRP threads were axially wrapped around the bars manually. The mechanical properties of the bars were investigated in the laboratory. The bars average ultimate tensile strength $\left(f_{u}\right)$ and elastic modulus $(E)$ were $1000 \mathrm{MPa}$ and $46 \mathrm{GPa}$, respectively. Four full-scale concrete hollow core slab specimens with characteristic strength of $80 \mathrm{MPa}$ were constructed and solely reinforced with a single prestressed GFRP bar. Each slab specimen represented one complete vent with a width of $140 \mathrm{~mm}, 150 \mathrm{~mm}$ thickness and $4000 \mathrm{~mm}$ total length. These specimens were simply supported during the experiments where the GFRP bar was placed at the centerline of the vent near the soffit. The Bars were prestressed to different stress levels, namely $(10,20,30$ and $40 \%)$ of their ultimate tensile strength $\left(f_{u}\right)$. All slab specimens were load-tested under uniformly distributed load. The deflection, strain and crack pattern were investigated during load-testing. From the obtained results, it was observed that the optimum prestressing level was $20 \%$ of the ultimate tensile strength of the bar for both the moment carrying capacity and the deformation.
\end{abstract}

KEYWORDS: GFRP Prestressing Bars; Hollow Core Slabs; Simply Supported Slabs; Uniformly Distributed Load Test

\section{INTRODUCTION}

A hollow core slab is a precast, prestressed concrete member with continuous voids provided to reduce weight and, therefore, cost. One advantage of using this system is to use it for concealed electrical or mechanical runs [1]. Primarily used as floor or roof deck systems, hollow core slabs also have applications as wall panels, spandrel members and bridge deck units. However, corrosion problems of steel reinforcing concrete structures exposed to aggressive environments such as roofs, liquid reservoirs, parking areas, bridges, and foundations has become a nagging problem for engineers.

Revised Manuscript Received on February 15, 2020.

* Correspondence Author

Awad M. Elhashimy, Assistant Professori, Department of Civil Engineering, Faculty of Engineering Mataria, Helwan University, Cairo, Egypt.

Waleed F. Tawhed, Assistant Professor, Department, of Civil Engineering Faculty of Engineering Mataria, Helwan University, Cairo, Egypt.

Mohamed H. Agamy, Teaching Assistant Department of Civil Engineering, Faculty of Engineering Mataria, Helwan University, Cairo, Egypt.

(C) The Authors. Published by Blue Eyes Intelligence Engineering and Sciences Publication (BEIESP). This is an open access article under the CC BY-NC-ND license (http://creativecommons.org/licenses/by-nc-nd/4.0/)
Hence, finding solutions to overcome this challenging problem became a very attractive area for research in recent years [2]. Use of Fiber Reinforced Polymers, (FRP), as pretension prestressing reinforcement for concrete structures, increased rapidly in the past decade. FRP reinforcement is made from high tensile strength fibers such as, carbon, glass, aramid, etc. in polymeric matrices produced in the form of bars, strands, tendons and grids, with wide variety of shapes and characteristics. FRP reinforcement is used as prestressing, non- prestressing and shear reinforcement for concrete structures [3].

\section{OBJECTIVES}

This research article presents the results of an investigation of the behavior of GFRP prestressing bars when pretensioned in concrete hollow core slab specimens. The objectives set forth for this research effort are:

1. Locally manufacture GFRP bars and obtain their different physical and mechanical properties.

2. Study the flexural behavior of pretensioned concrete hollow core slabs using reinforcing GFRP bars under uniformly distributed loads.

3. Examine the deformational behavior of pretensioned concrete hollow core slabs using reinforcing GFRP, in terms of deflection and strain distribution.

\section{BACKGROUND}

\section{A.Hollow Core Slabs}

Hollow core slabs are most widely known for providing economical, efficient floor and roof systems. The top surface can be prepared for the installation of a floor covering by feathering the joints with latex cement, installing non-structural fill concrete ranging from $1 / 2$ in to 2 in (13-51mm) thick depending on the materials used, or by casting a composite structural concrete topping. The soffit can be used as a finished ceiling as installed, by painting, or by applying an acoustical spray [4].

\section{B. Materials Used in Hollow Core Slabs}

Hollow core slabs are produced with two basic concrete mixes; low slump and normal slump concrete. For the low slump concrete, water content is limited to slightly more than that required for cement hydration. Water-to-cement ratio is typically about 0.3 . The water-cement ratio, cement and aggregate characteristics, concrete unit weight, type of curing and age, all play a significant role in the behavior [5].

\section{Published By:}

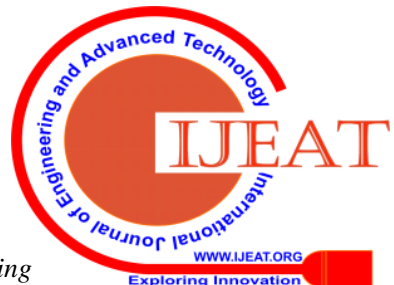




\section{Behavior of Hollow Core Slabs Reinforced with GFRP Prestressing Bars}

Mixing is critical because the limited water available must be well dispersed in the mix. Water reducing admixtures can be used to optimize a mix by reducing cement and water requirements while retaining adequate workability for proper mechanical compaction. Air entraining admixtures are not effective in the dry mix concrete. With the low water/cement ratio, compaction and placing method, air is difficult to disperse well and maintain [4].

\section{C.FRP Basics}

Glass fibers are the most common of all reinforcing fibers for polymeric matrix composites. The principal advantages of glass fibers are low cost, high tensile strength, high chemical resistance, and excellent insulating properties. The disadvantages are relatively low tensile modulus and high density (among the commercial fibers), and relatively low fatigue resistance. On the other hand, carbon fibers are available with a variety of tensile modulus [6].

In general, the low-modulus fibers have lower density, lower cost, higher tensile and compressive strengths, and higher tensile strains-to-failure than the high-modulus fibers. Among the advantages of carbon fibers are their exceptionally high tensile strength, very low coefficient of linear thermal expansion, low inter-laminar shear strength, high fatigue strengths, and high thermal conductivity [6].

\section{D.Prestressing Using GFRP Bars}

FRP tendons are available in the form of rods or cables, rectangular strip, braided rod and multi wire strand. One problem with external FRP tendons is the anchorage. Due to its anisotropy as a material, perpendicular forces might crush the FRP tendon, which has been a fact for some wedge systems. However, newer systems seem to overcome this problem [6].

EMPA Switzerland has developed a system where they use a conical anchorage system. Special anchors are required for testing FRP rods and bars by inserting their ends into steel cylinders that are subsequently filled with either a polymer resin or a cement-based grout as described in ACI [7]. A specified standard method to determine the FRP bar tensile properties were covered by the CSA [8] and the ASTM [9]. Further, a specified standard method to determine the ensile properties of (GFRP) bars provided in cut lengths and having an external surface enhancement for concrete reinforcement was described in the ASTM [10]. In general, the anchor casing is made of steel, but it can also be made of a fiber composite [11].

\section{E.Bond Strength between GFRP Bars and Concrete}

The bond properties of FRP bars have been extensively investigated by numerous researchers through different types of tests, such as pull-out tests, splice tests, and cantilever beams, to determine an empirical equation for embedment length [12] and [13]. The bond stress of a particular FRP bar should be based on test data provided by the manufacturer using standard test procedures that are still under development at this time. A specified standard method to determine the FRP bar bond strength with concrete is presented in the ACI [7] and CAS [8].

\section{F. Behavior of Prestressed Concrete}

Pre-stressed concrete is reinforced concrete in which the steel reinforcement has been tensioned against the concrete. This tensioning operation results in a self-equilibrating system of internal stresses (tensile stress in the steel and compressive stresses in the concrete) which improves the response of the concrete to external loads. [14].

\section{EXPERIMENTAL PROGRAM}

The experimental program carried out in this research work is divided into four phases; 1: GFRP bar manufacture, 2: Slab specimen construction, 3: Prestressing the bars during slab construction and, finally, 4: Full load-testing of the specimens. Detailed description of each phase is presented in the following sections.

\section{A.Manufacture of GFRP Bars}

The GFRP bars were manually manufactured in the materials laboratory in the faculty of Engineering, Mataria, Helwan University, Cairo, Egypt. The manufactured bars were smooth $10 \mathrm{~mm}$ diameter bars which were converted into deformed bars by axially wrapping FRP threads around them to improve their bond properties. Manufacture details are presented in the following sub-sections.

\section{Materials}

The raw materials used in the manufacture of the bars were; continuous type E-Glass fibers and the binding matrix is polyester resin. The raw materials are commercially available in the Egyptian market which is considered a feasible and economic factor to be achieved. The pultrusion method was used in the manufacture of the GFRP bars.

The glass fibers possess useful properties including ease of chopping, ease of rolling and adequate affinity to resin which make them a good choice for bar manufacture. The fibers had a linear weight of roving of $2400 \mathrm{~g} / \mathrm{m}$.

The binding resin was polyester ES-1319 which possess high self-extinguishing properties with medium viscosity and medium reactivity. The self-extinguishing properties of the resin were due to the change in the molecular composition and not to the halogenated additives. This property allows for obtaining products with good fire resistance. A small percentage of peroxide (8-10\%) was mixed with the polyester resin to accelerate the hardening process of the resin.

\section{Pultrusion Manufacture Process of GFRP Bars}

The pultrusion process is one of the most cost-effective methods to produce composite materials. It is a continuous process which produces high quality, with constant cross section, bars. For that reason, it is possible to use it to fabricate complex geometries. Fig. 1 presents the mechanical pultrusion process which was adopted in the manufacture of the GFRP bars used in this research. The process can be summarized in six stages as shown in Fig. 1 as follows:

a) Continuous fibers are pulled from a series of creels.

b) The fibers are roved through a resin bath where the resin was mixed with peroxide at ratio of 500: 1 by weight to pultrude the bar. 
c) The impregnating fibers with resins are pulled through a heated steel mold.

d) The bars continuously exit the mold where the elevated temperature cures the composite matrix into a constant cross section.

e) The bars are continuously pulled by a machine to

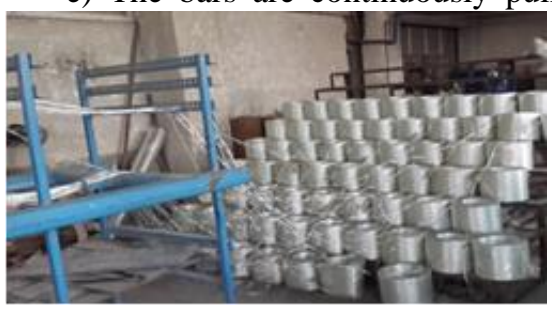

a) Fiber Creels

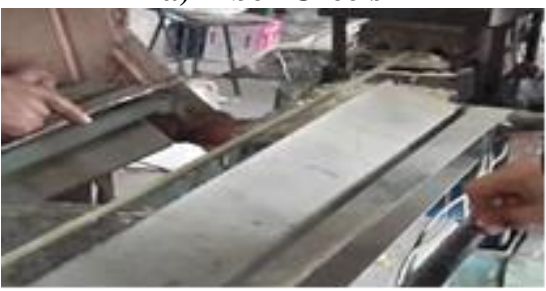

d) Bars Exit Heated Mold

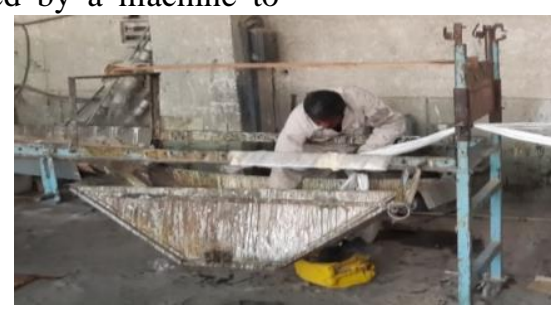

b) Resin Tank

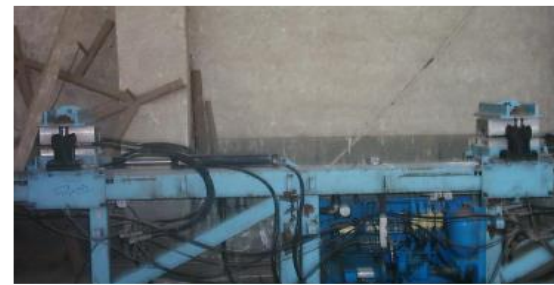

e) Pulling Machine maintain their cross section and up to the required bar length.

f) The final bars are cut to required length and prepared to add deforms.
Fig. 1. Manufacture Process of the GFRP Bars

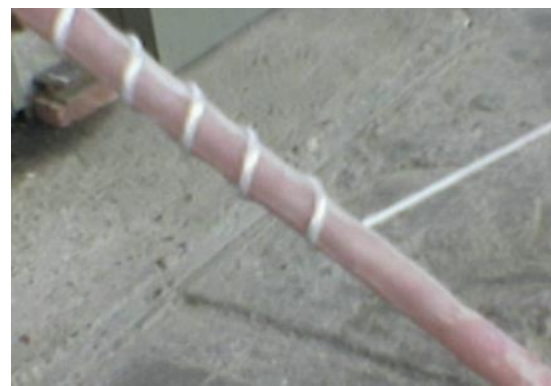

a) Wrapping Threads

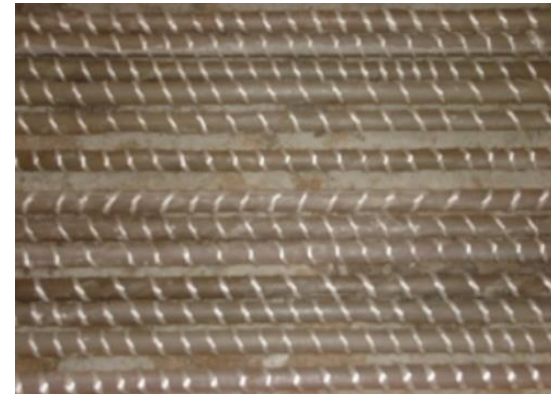

b) Final Product
Fig. 2. Manual Wrapping of Fiber Yarns on the GFRP bars

\section{Wrapping of fiber yarns on GFRP bars}

The bond strength between the GFRP bars and concrete is very important to improve the capacity of the structural elements. The GFRP bars needed to be equivalent to the deformed steel bars in the bond strength with concrete. Therefore, to increase the bars surface area it was decided to manually wrap fiber yarns around the bars in a helical shape at somewhat a constant pitch as shown in Fig. 2. After wrapping the fiber yarns the bars are immersed in the resin with peroxide mixture tank to cover the new bar surface area.

\section{Properties of GFRP Bars}

After the GFRP bars were manufactured, tests were performed to determine their physical and mechanical properties. The physical properties determined were; the fiber volume fraction and the unit weight of the GFRP bars. In addition, the tested mechanical properties were; the bond strength between the bars and concrete, ultimate tensile strength, tensile failure strain and modulus of elasticity. The average mechanical properties of the bars are summarized in Table-I.
Table-I: Average Mechanical Properties of GFRP Bars

\begin{tabular}{|c|c|c|c|c|c|}
\hline $\begin{array}{c}\text { Diameter } \\
(\mathrm{mm})\end{array}$ & $\begin{array}{c}\text { Area } \\
\left(\mathrm{mm}^{2}\right)\end{array}$ & $\begin{array}{c}\text { Ultimate } \\
\text { Tensile } \\
\text { Load }(\mathrm{kN})\end{array}$ & $\begin{array}{c}\text { Ultimate } \\
\text { Tensile } \\
\text { Strength } \mathrm{f}_{\mathrm{u}} \\
(\mathrm{MPa})\end{array}$ & $\begin{array}{c}\mathrm{E} \\
(\mathrm{GPa})\end{array}$ & $\begin{array}{c}\text { Ultimate } \\
\text { Tensile } \\
\text { Strain }(\%)\end{array}$ \\
\hline 10 & 78.5 & 85 & 1082.8 & 46.8 & 2.3 \\
\hline
\end{tabular}

\section{B.Slab Specimens Preparation}

\section{Slab Specimens}

Four full-scale high strength concrete (80 MPa) one-vent precast prestressed strip of hollow core slabs were constructed and tested under uniform and distributed load at the laboratory. All the slabs were $150 \mathrm{~mm}$ thick, $142 \mathrm{~mm}$ wide and $4200 \mathrm{~mm}$ long as shown in Fig. 3. The $150 \mathrm{~mm}$ thickness of the slabs was governed by the production schedule of most manufacturers, the $142 \mathrm{~mm}$ slab width was centerline to centerline of a hollow duct as the production schedule of most manufacturers as well. As for the span length, it was chosen to be $4000 \mathrm{~mm}$, which was typical for the $150 \mathrm{~mm}$ thick slabs.

\section{Published By:}

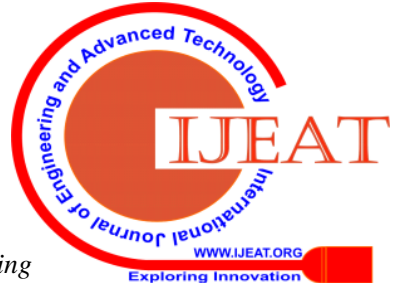


The bar was placed $25 \mathrm{~mm}$ from the slab soffit as shown in Fig. 3.

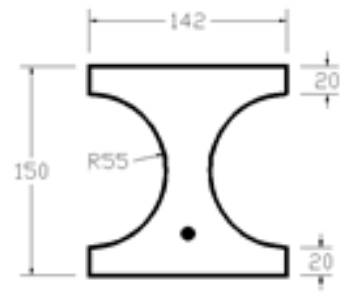

Fig. 3. One-Vent Slab Strip Dimensions (mm)

The slabs were reinforced with a single low relaxation pretensioned $10 \mathrm{~mm}$ diameter GFRP bar and were simply supported and subjected to uniformly distributed load as presented in Fig. 4.

uniform load

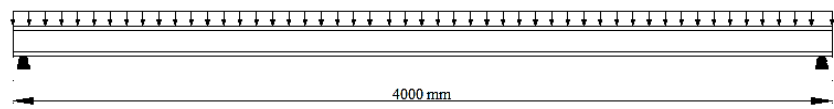

Fig. 4. Test Setup of Simply Supported Slabs

Each slab of the four specimens was reinforced with a single GFRP bar pretensioned with different percentage of the average ultimate strength of the bars. The pretension level ranged from $0.1 f_{u}$ to $0.4 f_{u}$ as shown in Table-II.

\section{Table-II: Pretension Level of the Slab Specimens}

\begin{tabular}{|c|c|}
\hline Specimen ID & $\begin{array}{c}\text { Pretension Level of } \\
\text { GFRP Bars }\end{array}$ \\
\hline HC0.1S & $0.1 \mathrm{f}_{\mathrm{u}}$ \\
\hline $\mathrm{HC} 0.2 \mathrm{~S}$ & $0.2 \mathrm{f}_{\mathrm{u}}$ \\
\hline $\mathrm{HC} 0.3 \mathrm{~S}$ & $0.3 \mathrm{f}_{\mathrm{u}}$ \\
\hline $\mathrm{HC} 0.4 \mathrm{~S}$ & $0.4 \mathrm{f}_{\mathrm{u}}$ \\
\hline
\end{tabular}

Fabrication of Slab Specimens

The slab specimens were manufactured in a controlled environment in the materials laboratory at Helwan University using local materials to achieve high quality control to resemble the manufacturer's factory products. Metal forms were used for casting the slabs with very stiff plumbing tubes fixed to each side of the forms to obtain the required specimen shape, as shown in Fig. 5.

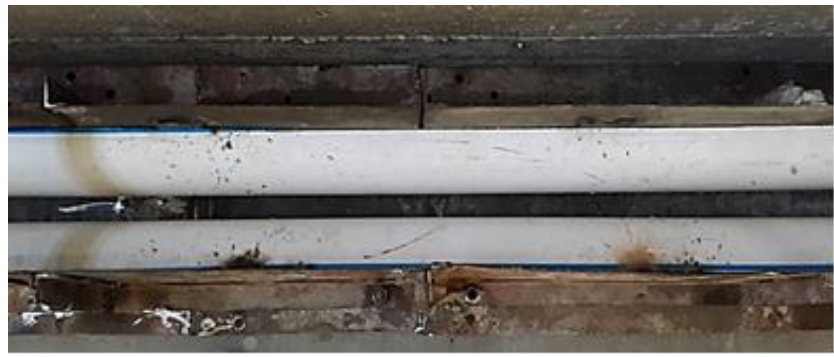

Fig. 5. Formwork of Slab Mold

\section{C.Prestressing GFRP Bars during Concrete Casting}

A pretension jack was used to pull the bar out by applying a load sufficient to introduce the level of the required pretension on the bar during slab specimen casting as shown in Fig. 6. A load cell was used to record the required prestressing force. Wedge anchors were used as a grip for the bar during pretension process to maintain the prestressing force on the bar as shown in Fig. 7. Fig. 8 shows the complete casting setup and prestressing jack for the concrete slab specimens.

\section{D.Full-Scale Load Testing Setup for Specimen}

The full-scale load testing setup is shown in Fig. 9. The test setup consisted of a loading frame, a loading system (hydraulic jack connected to load cells and load distribution steel I-beams), LVDT's, and supporting steel I-beams. Steel C-channels were directly placed on the surface of the hollow core slab at a constant pitch underneath four $900 \mathrm{~mm}$ long steel I-beams was placed on these C-channels. A series of 4 mm thick greased neoprene pads were placed between the I-beams and the C-channels for uniform distribution of the vertical jack load.

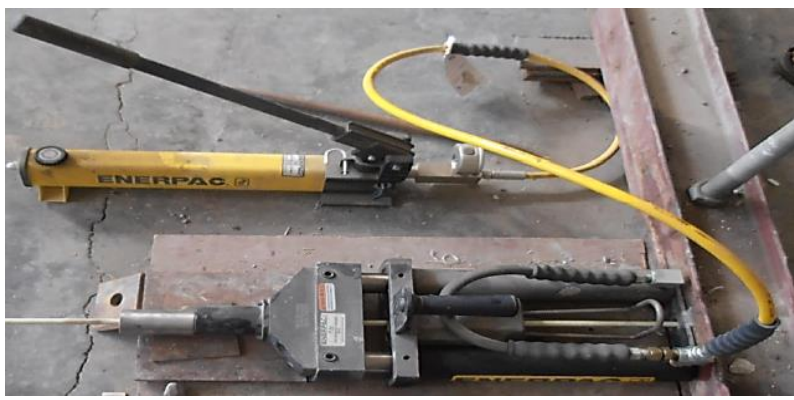

Fig. 6. Prestressing Jack

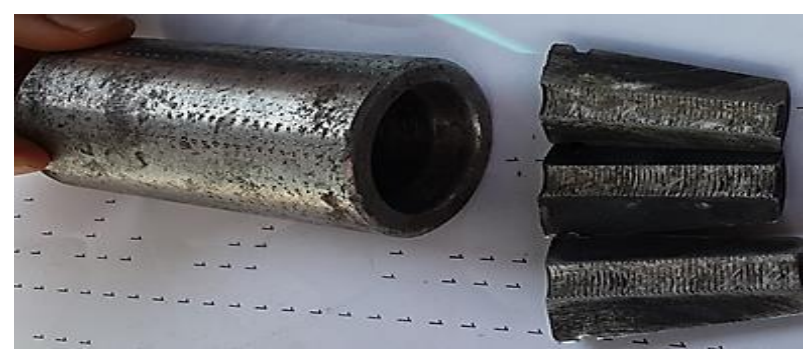

Fig. 7. Wedge Anchors

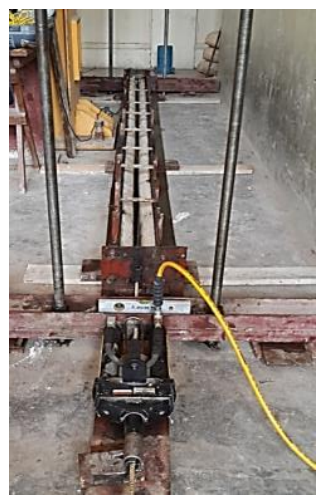

Fig. 8. Casting and Prestressing Setup

To simulate the lateral support of the adjacent vents of the hollow core slabs, two rigid steel channels with stiffeners were clamped to the sides of the slab specimens. In addition, each specimen was laterally braced to prevent out of plane rotation of any of the loading setup mechanism as shown in Fig. 9(b). The load was successively transmitted to the hollow core slab from the main steel I-beam underlain by two I-beams with pin supports. The load was applied to the hollow core slabs as a uniformly along the slab length via distribution steel I-beams. The loading sequence was load-controlled stepwise loading process. 


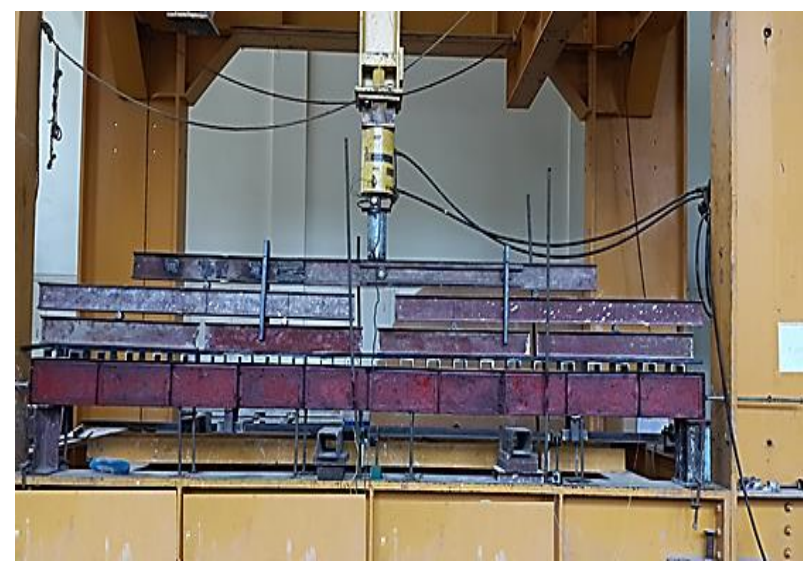

a) Uniformly Distributed Load Test Setup

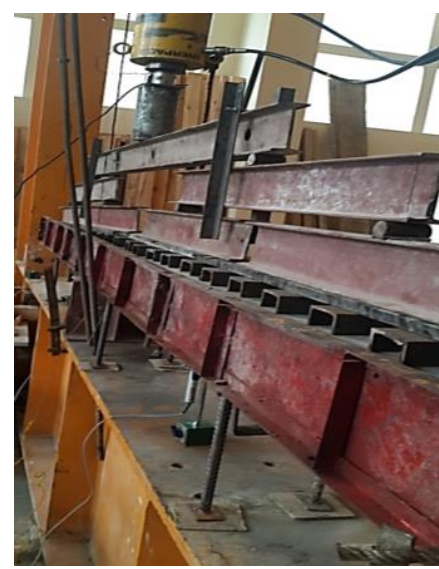

b) Out of Plane Bracing

Fig. 9. Full-Scale Load Testing Setup for Simply Supported Slab Specimens resolution and $\pm 1 \%$ accuracy LVDTs. Pretension bar slippage was recorded by analog dial gauges with $0.01 \mathrm{~mm}$ precession. The hydraulic jacks applied the load in increments while the LVDTs and gages readings were recorded.

\section{RESULTS AND ANALYSIS}

The results of the monotonic loading tests using uniformly distributed loads are summarized in Table 3. It is worth noting that cracks in all slab specimens were formed and propagated within the flexural zone and across the slab width. As shown in Table-III, the load testing was not completed on Specimen HC0.4S which was pretensioned to $40 \%$ of the ultimate load of the bar as the bars were crushed when the grips were applied. This might be explained, that due to the high tensile stresses applied to the bar and when the ends were subjected to compressive stresses due to the grip, the stresses exceeded the materials capacity and were crushed. In the subsequent sections, a discussion of the effects of pretensioned GFRP bars under a uniformly distributed load will be presented for only the three successfully loaded slab specimens.

Table-III: Load and Moment Results of the Simply Supported Hollow Core Slabs

\begin{tabular}{|c|c|c|c|c|}
\hline \multirow{2}{*}{$\begin{array}{c}\text { Specimen } \\
\text { ID }\end{array}$} & \multicolumn{2}{|c|}{$\begin{array}{c}\text { Uniformly Distributed } \\
\text { Load }(\mathrm{kN} / \mathrm{m})\end{array}$} & \multirow{2}{*}{$\begin{array}{c}\text { Initial } \\
\text { Cracking } \\
\text { Moment } \\
(\mathrm{kN} . \mathrm{m})\end{array}$} & $\begin{array}{c}\text { Ultimate } \\
\text { Moment } \\
(\mathrm{kN} . \mathrm{m})\end{array}$ \\
\cline { 2 - 4 } & $\begin{array}{c}\text { Initial } \\
\text { Crack Load }\end{array}$ & $\begin{array}{c}\text { Ultimate } \\
\text { Load }\end{array}$ & 2.64 & 6.30 \\
\hline HC0.1S & 1.23 & 3.18 & 3.65 & 8.16 \\
\hline HC0.2S & 1.85 & 4.08 & 2.27 & 6.30 \\
\hline HC0.3S & 1.14 & 3.15 & \multicolumn{3}{|c|}{ Bars were crushed after placing the grips } \\
\hline HC0.4S & \multicolumn{4}{|c}{} \\
\hline
\end{tabular}

\section{A.Effects of Pretension Stress Level on the Load and Moment Capacity of Slabs}

The hollow core slab specimens were reinforced with pretensioned GFRP bars at different levels (0.1, 0.2 and 0.3 $\mathrm{f}_{\mathrm{u}}$ ). The glass fiber yarns composing the GFRP bars were affected with the pretension force, therefore, the stiffness and the energy absorb affected by bar varies.

Fig. 10 presents a comparison between the initial crack load and ultimate failure load for all tested slabs. From Fig.
Vertical displacements were recorded using $1 \mu \mathrm{m}$

10 , it is observed that the initial crack for the slab prestressed by $20 \% \mathrm{f}_{\mathrm{u}}$ was higher than the $10 \%$ and $30 \% \mathrm{f}_{\mathrm{u}}$ by 50 and 62 $\%$, respectively. However, it is observed that the ultimate failure load for the slab prestressed by $20 \% \mathrm{f}_{\mathrm{u}}$ was 28 and 30 $\%$, respectively higher than the $10 \%$ and $30 \% \mathrm{f}_{\mathrm{u}}$ slabs.

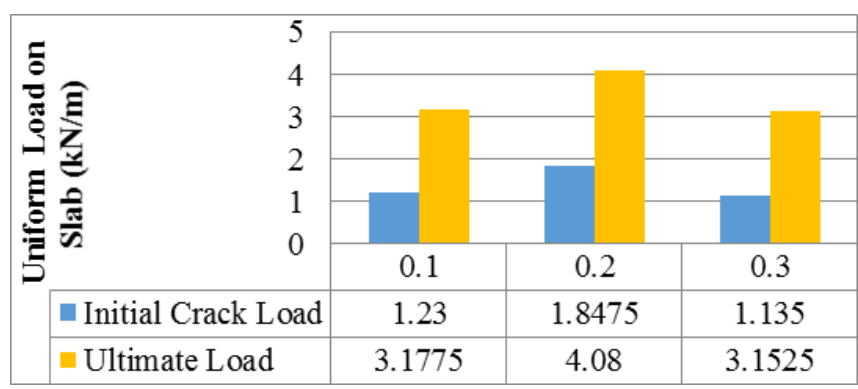

Fig. 10: Initial Crack and Ultimate Load at Different Prestressing Levels

Fig. 11 shows the load and midspan deflection relationship of the three tested slabs. From Fig. 11, it is noticed that, at failure, the slab which was prestressed by $20 \% \mathrm{f}_{\mathrm{u}}$ experienced a higher midspan deflection than the other two slabs ( 0.1 and $0.3 \mathrm{f}_{\mathrm{u}}$ ). The increase in midspan deflection from the slab which was prestressed by $20 \% \mathrm{f}_{\mathrm{u}}$ to the 0.1 and $0.3 \mathrm{f}_{\mathrm{u}}$ is about 1.5 and $18 \%$, respectively.

This observation depicts that the slab which was prestressed by $20 \% \mathrm{f}_{\mathrm{u}}$ exhibited the highest energy absorption than the other two slabs despite their original initial stiffness. Moreover, if at the maximum deflection of slab 0.3fu, the load is compared it is found that the load of $0.2 \mathrm{f}_{\mathrm{u}}$ slab increased by $6 \%$ while the load of $0.1 \mathrm{f}_{\mathrm{u}}$ slab decreased by $10 \%$.

The cracking and ultimate moments of all the tested slabs are presented in Fig. 12. From Fig. 12, it is observed that the pretensioned GFRP bar significantly increased the moment resistance of the slab which was prestressed by $20 \% \mathrm{f}_{\mathrm{u}}$ over the other prestressing level slabs. The ultimate moment increased by about $30 \%$ than the other two slabs. In addition, the cracking moment increased by about $38 \%$ than the $0.1 \mathrm{f}_{\mathrm{u}}$ and about $61 \%$ than the $0.3 \mathrm{f}_{\mathrm{u}}$ slab.

\section{Published By:}

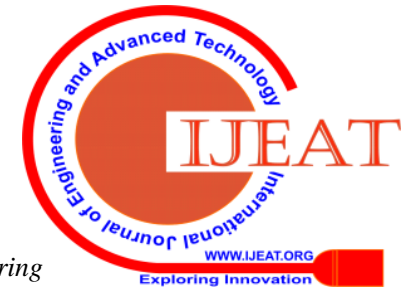




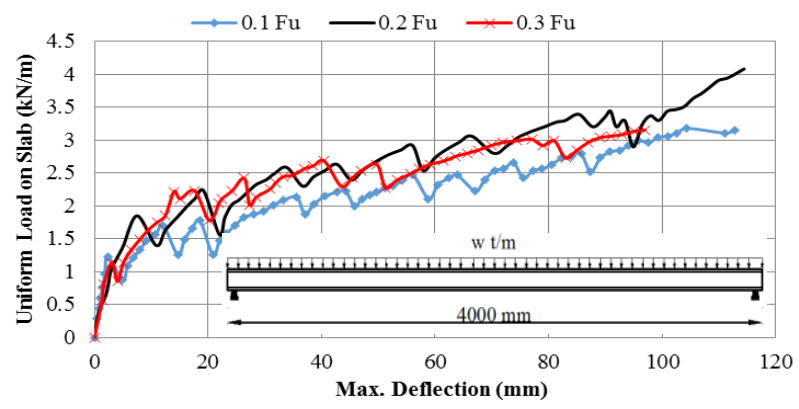

Fig. 11: Load vs. Midspan Deflection at Different Prestressing Levels

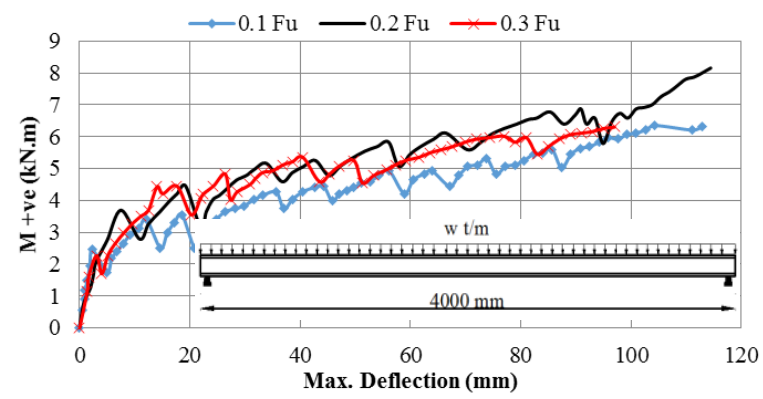

Fig. 12: Midspan Moment vs. Midspan Deflection at Different Prestressing Levels

From the previous discussion, it could be concluded that the increase of the GFRP prestressing level, increases both the ultimate load and ultimate moment of the slab up to $20 \%$ $f_{u}$. However, increasing the stress level beyond $20 \% f_{u}$ gradually decreases both the ultimate load and moment. This could be explained by loss of integrity of the GFRP bars at higher pretension force where a larger number of the fiber yarns would be broken and, thus, affects the composite behavior when embedded in the concrete member.

\section{B.Effects of Pretension Stress Level on the Maximum Mid span Deflection of Slabs}

Fig. 13 shows the maximum deflection profile along the slab length of the simply supported hollow core slabs due to different prestressing forces $\left(0.1,0.2\right.$ and $\left.0.3 \mathrm{f}_{\mathrm{u}}\right)$ at failure. From Fig. 13, it is shown that the slab which was prestressed by $20 \% \mathrm{f}_{\mathrm{u}}$ experienced the highest deflections along the slab length. While the slab which was prestressed by $10 \% \mathrm{f}_{u}$ experienced the lowest deflection profile due to the prestressing effect of the baron the slab. On the other hand, it is noticed that deflection profile of the $0.1 \mathrm{f}_{\mathrm{u}}$ showed insignificantly lower values than the $0.2 \mathrm{f}_{\mathrm{u}}$ slab.

\section{C.Effects of Pretension Stress Level on the Tensile Stress of the GFRP Bar}

The stresses in the bar were calculated from the resulting strain on the bar during loading based on the stress-strain relationship of the bar obtained from the initial uniaxial tensile test. Fig. 14 presents the relation between stress and strain in the bar at different prestressing levels during load testing in the slabs. From Fig. 14, it is observed that the maximum stress level at failure was for bar prestressed with $0.3 \mathrm{f}_{\mathrm{u}}$, while both bars stressed with $0.1 \mathrm{f}_{\mathrm{u}}$ and $0.2 \mathrm{f}_{\mathrm{u}}$ with almost the same stress level at failure, but at different strain since the $0.1 \mathrm{f}_{\mathrm{u}}$ bar possesses more strain at the same stress level.

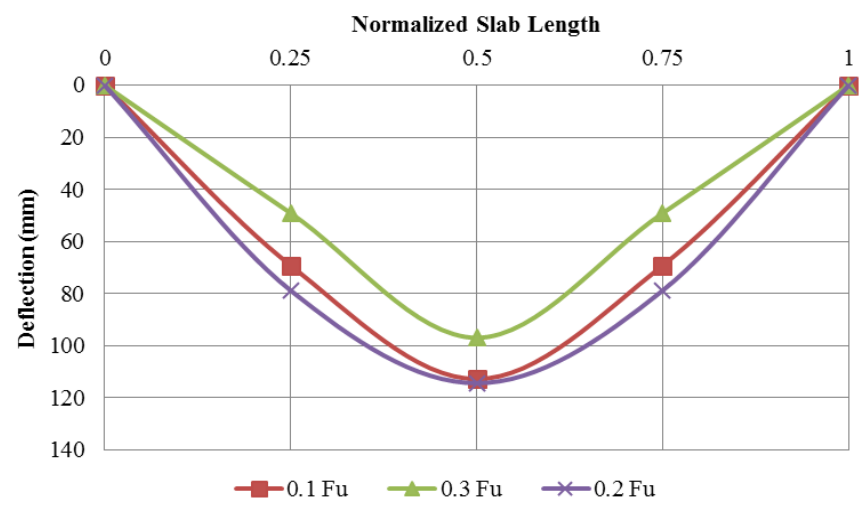

Fig. 13: Maximum Midspan Deflection along Slab Length at Different Prestressing Levels

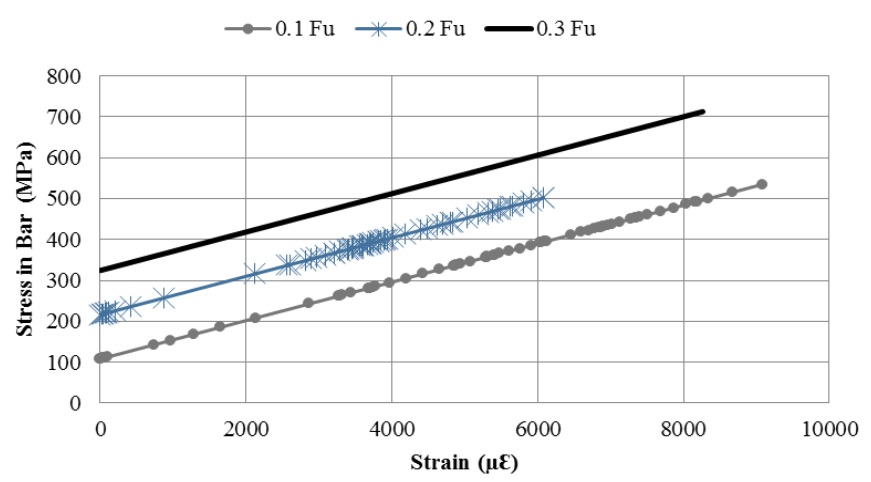

Fig. 14: Calculated Stress vs Strain in the Bars at Different Prestressing Levels

\section{D.Effects of Pretension Stress Level on Energy Absorption}

Energy absorption is represented by the material toughness and resilience which are determined from the areas under the load-deflection curve for each specimen. The two properties are indications of the elasto-plastic behavior of the structural element. Fig. 15 and Fig. 16, respectively, present the variation of the toughness and resilience with the pretension levels for all slabs. From both Fig. 15 and Fig.16, it is observed that slab which was prestressed by $30 \% \mathrm{f}_{\mathrm{u}}$ experienced the least energy absorption in the elastic range and until failure.

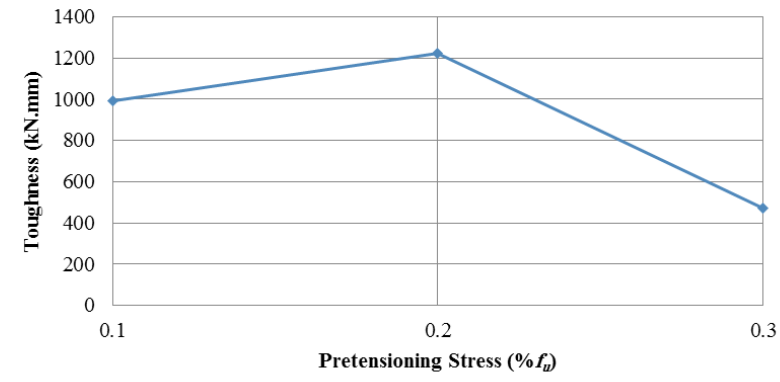

Fig. 15: Slab Toughness at Different Prestressing Levels

In contrast the slab which was prestressed by $20 \% \mathrm{f}_{u}$ experienced the highest energy absorption in the elastic range and until failure. 
It is observed that the increase in toughness experienced by the $0.2 \mathrm{f}_{\mathrm{u}}$ slab is about $23 \%$ and $161 \%$ for the $0.1 \mathrm{f}_{\mathrm{u}}$ and $0.3 \mathrm{f}_{\mathrm{u}}$ slabs, respectively. On the other hand, the increase in resilience experienced by the $0.2 \mathrm{f}_{\mathrm{u}}$ slab is about $384 \%$ and $800 \%$ for the $0.1 f_{u}$ and $0.3 f_{u}$ slabs, respectively.

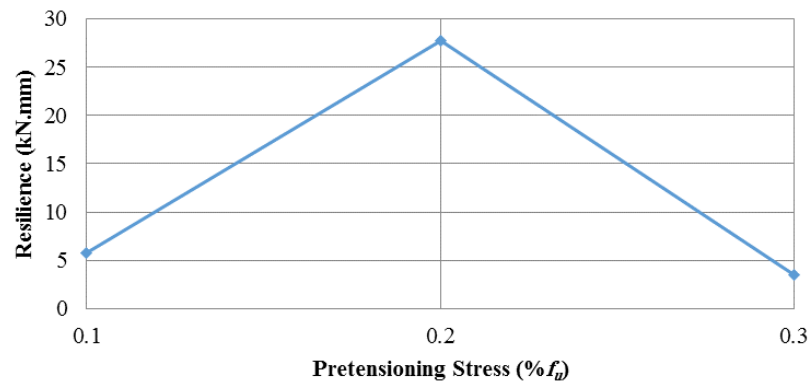

Fig. 16: Slab Resilience at Different Prestressing Levels

\section{E. Effects of Pretension Stress Level on the Strain in the Bar within the Slab}

Fig. 17 presents the relation between the uniform load on the slab and the strain in the GFRP bar under different pretension levels. train at failure for slabs of $0.2 \mathrm{f}_{\mathrm{u}}$ was a minimum strain about $6.07 \%$ at the highest force by $3.51 \mathrm{kN}$. Also, the initial cracking load for that specimen was the highest value at low strain in bar at elastic zone. The strains at failure were $9.08 \%, 6.077 \%$ and $8.3 \%$ for slabs $0.1 \mathrm{f}_{\mathrm{u}}, 0.2 \mathrm{Fu}$ and $0.3 \mathrm{f}_{\mathrm{u}}$, respectively. The unexpected load strain curve by decreasing of strain for slab of $0.3 \mathrm{f}_{\mathrm{u}}$ by $37 \%$ than that slab of $0.2 \mathrm{f}_{\mathrm{u}}$ due to bar yarns break. Also, the effect of bar

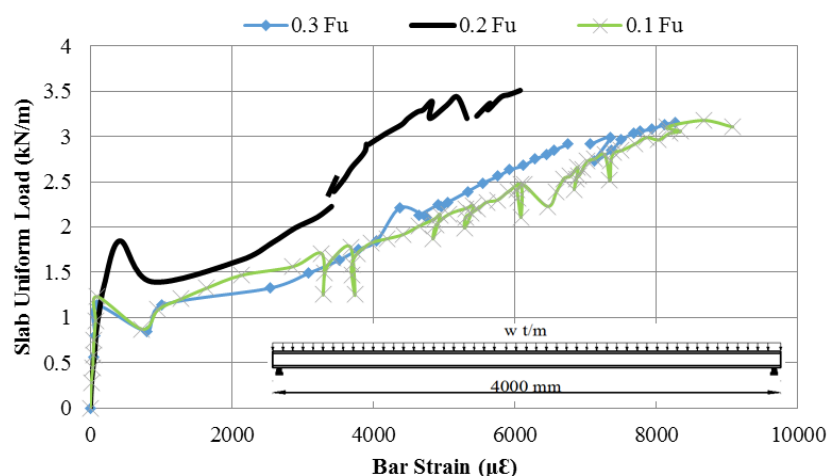

Fig. 17: Slab Uniform Load vs Strain in Bar at Different Prestressing Force

\section{SUMMARY \& CONCLUSIONS}

An experimental program was designed to study the behavior of full-scale hollow core slabs reinforced with prestressed locally manufactured Glass Fiber-Reinforced Polymer (GFRP) bars and load-tested under uniform load. Prestress level ranged between 10 and $40 \%$ of the ultimate strength of the bars. The deflection of the slabs and the strain in the bars were measured.

From the herein presented discussions of the results obtained, several conclusions could be drawn as:

1. The maximum pretension force to be applied on the GFRP bars should not be more than 0.3 of the ultimate tensile force due to fracture of GFRP.

2. Simply supported slabs tested under uniformly prestressing level is due to the flexural mode of failure.

distributed load experience a direct relation between the ultimate load and the pretension force of GFRP bar up to $0.2 \mathrm{f}_{\mathrm{u}}$.

3. The highest initial cracking load was observed at a pretension force of $0.2 \mathrm{f}_{\mathrm{u}}$. So, it is recommended to use this stress level when designing hollow core elements prestressed with GFRP bars.

4. The simply supported hollow core slab which was prestressed by $20 \% \mathrm{f}_{\mathrm{u}}$ experienced the highest elastic and plastic energy absorption.

5. Prestressing hollow core slab with GFRP bars provide ductile flexural failure for prestressing levels lower than $0.3 \mathrm{fu}_{\mathrm{u}}$.

6. Deformed prestressing GFRP bars show no bond failure during uniformly distributed loading at all stress levels.

\section{REFERENCES}

1. Vidya Jose, P. Rajeev Kumar, 2014. "Hollow Core Slabs in Construction Industry", International Conference on Innovations \& Advances in Science, Engineering and Technology, Toc H Institute of Science \& Technology, Arakunnam, Kerala, India, Vol. 3, Special Issue 5, July 16-18, ISSN 2319-8753, pp 414-420.

2. Donald R. Buettner and Roger J. Becker Computerized Structural Design, S.C., 1998. "PCI Manual for the Design of Hollow Core Slabs," $2^{\text {nd }}$ Edition, PCI Precast/Prestressed Concrete Institute,175 West Jackson Blvd, Chicago, IL. ISBN 0-937040-57-6, 141 pp.

3. Karbhari V.M., 1998. "Use of Composite Materials in Civil Infrastructure in Japan," WTEC Final Report, International Technology Research Institute, R.D. Shelton, Director, 4501 North Charles Street Baltimore, Maryland. ISBN 1-883712-50-5, 211 pp.

4. Pincheira, J.A. and Woyak, J.P., 2001. "Anchorage of Carbon Fiber Reinforced Polymer (CFRP) Tendons Using Cold-Swaged Sleeves,' PCI Journal, Vol. 46, No. 6, Nov.-Dec., pp 100-111.

5. Carreira, D.J., and Chu, KH., 1985. "Stress-Strain Relationship for Plain Concrete in Compression,” ACI Journal, Vol. 82, No. 6, Nov.-Dec. pp 797-804.

6. Mallick, P.K., 1988. "Fiber Reinforced Composites, Materials, Manufacturing, and Design," CRC Press; $3^{\text {rd }}$ Edition, Marcell Dekker, Inc., New York, 469 pp.

7. ACI 440.1R-06, 2006. "Guide for the Design and Construction of Concrete Reinforced with FRP Bars," ACI, American Concrete Institute, Farmington Hills, MI.

8. Canadian Standards Association (CSA S807-19), 2019. "Specification for Fiber Reinforced Polymers," CSA Group, Rexdale, Ontario, Canada, August 2019.

9. ASTM D7205/D7205M-06, 2016. "Standard Test Method for Tensile Properties of Fiber Reinforced Polymer Matrix Composite Bars,", Annual Book of ASTM Standards, Vol. 15.03, ASTM, West Conshohocken, PA.

10. ASTM D7957/D7957M-17, 2017. "Standard Specification for Solid Round Glass Fiber Reinforced Polymer Bars for Concrete Reinforcement," Annual Book of ASTM Standards, Vol. 15.03, ASTM, West Conshohocken, PA.

11. Meier, U., 1998, US-Patent 5,713,169, Feb 3.

12. Benmokrane B., Zhang B. and Chennouf A., 2000. "Tensile Properties and Pullout Behavior of AFRP and CFRP Rods for Grouted Anchor Applications," Construction and Building Materials, Vol. 14, No. 3, Elsevier Science Ltd., April, pp 157-170.

13. Faza, S.S., and GangaRao, H.V.S., 1991. "Bending and Bond Behavior of Concrete Beams Reinforced with Plastic Rebars," Transportation Research Record, Proceedings: $3^{\text {rd }}$ Bridge Engineering Conference, Denver, Colorado, Vol. 2, No. 1290, March 10-13, ISBN: 0309050677 pp 185-193.

14. Collins, M.P. and Mitchell, D., 1991. "Prestressed Concrete Structures", Prentice Hall International Series in Civil Engineering and Engineering Mechanics, Prentice Hall, Englewood Cliffs, New Jersey, ISBN: 978-0136916352, 766 pp.

\section{Published By:}

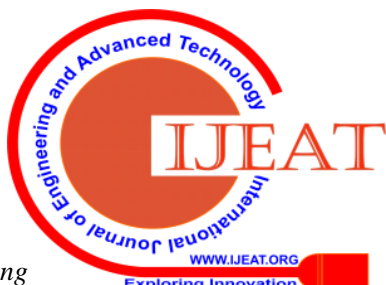




\section{AUTHORS PROFILE}

Awad M. Elhashimy, is an Assistant Professor in Civil Engineering Department, Faculty of Engineering at Mataria, Helwan University, Cairo, Egypt. He has received his Ph.D. degree from the University of Innsbruck, Innsbruck, Austria in 2002. He is specialized in strength and properties of materials and repair using composites. His research interests include; behavior and construction of concrete materials, behavior and use of composite materials in repair and strengthening of concrete and steel structures, in addition to numerical modeling of concrete materials. Dr. Elhashimy is active in research and academic supervision on numerous engineering post-graduate students in the field of material science.

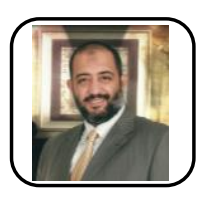

Waleed F. Tawhed, is an Assistant Professor in Civil Engineering Department, Faculty of Engineering at Mataria, Helwan University, Cairo, Egypt. He has received his Ph.D. degree from the University of South Carolina, Columbia, USA in 2005. He is specialized in strength and properties of materials and Non-Destructive testing. His research interests include; behavior and construction of concrete materials, non-destructive evaluation and non-destructive testing of concrete and masonry materials, behavior and applications of modern composite materials in repair and strengthening of concrete structures, in addition to studying innovative techniques for recycling organic materials to be used in concrete structures. Dr. Tawhed is active in research and academic supervision on numerous engineering post-graduate students in the field of material science.

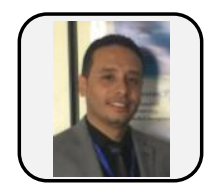

Mohamed H. Agamy, is a Teaching Assistant in Civil Engineering Department, Faculty of Engineering at Mataria, Helwan University, Cairo, Egypt. He is specialized in Structure Analysis and modeling. His research interests include; behavior and construction of concrete materials, use of advanced composite materials in repair and strengthening of concrete structures, behavior and design of recycled concrete elements in addition to numerical and experimental structural modeling of concrete and steel structures. 